Volume 2

Number 3 The Globalization Hiccup

Article 4

2017

\title{
Antinomies of Globalization
}

Yahya Mete Madra

Drew University

Follow this and additional works at: https://digitalcommons.uri.edu/mgdr

Part of the Economic History Commons, Growth and Development Commons, International

Economics Commons, International Relations Commons, Political Economy Commons, Political Theory

Commons, and the Sociology Commons

\section{Recommended Citation}

Madra, Yahya Mete (2017) "Antinomies of Globalization," Markets, Globalization \& Development Review. Vol. 2: No. 3, Article 4.

DOI: 10.23860/MGDR-2017-02-03-04

Available at: https://digitalcommons.uri.edu/mgdr/vol2/iss3/4

This Article is brought to you for free and open access by DigitalCommons@URI. It has been accepted for inclusion in Markets, Globalization \& Development Review by an authorized editor of DigitalCommons@URI. For more information, please contact digitalcommons-group@uri.edu. 


\section{Antinomies of Globalization}

\section{Cover Page Footnote}

The author wishes to thank Deniz Atik, Emelio Betances, Nikhilesh Dholakia, Lara Fresko, Aras Özgün, Ceren Özselçuk, and Maliha Safri for their comments. The usual disclaimer applies. 


\section{Markets, Globalization \& Development Review}
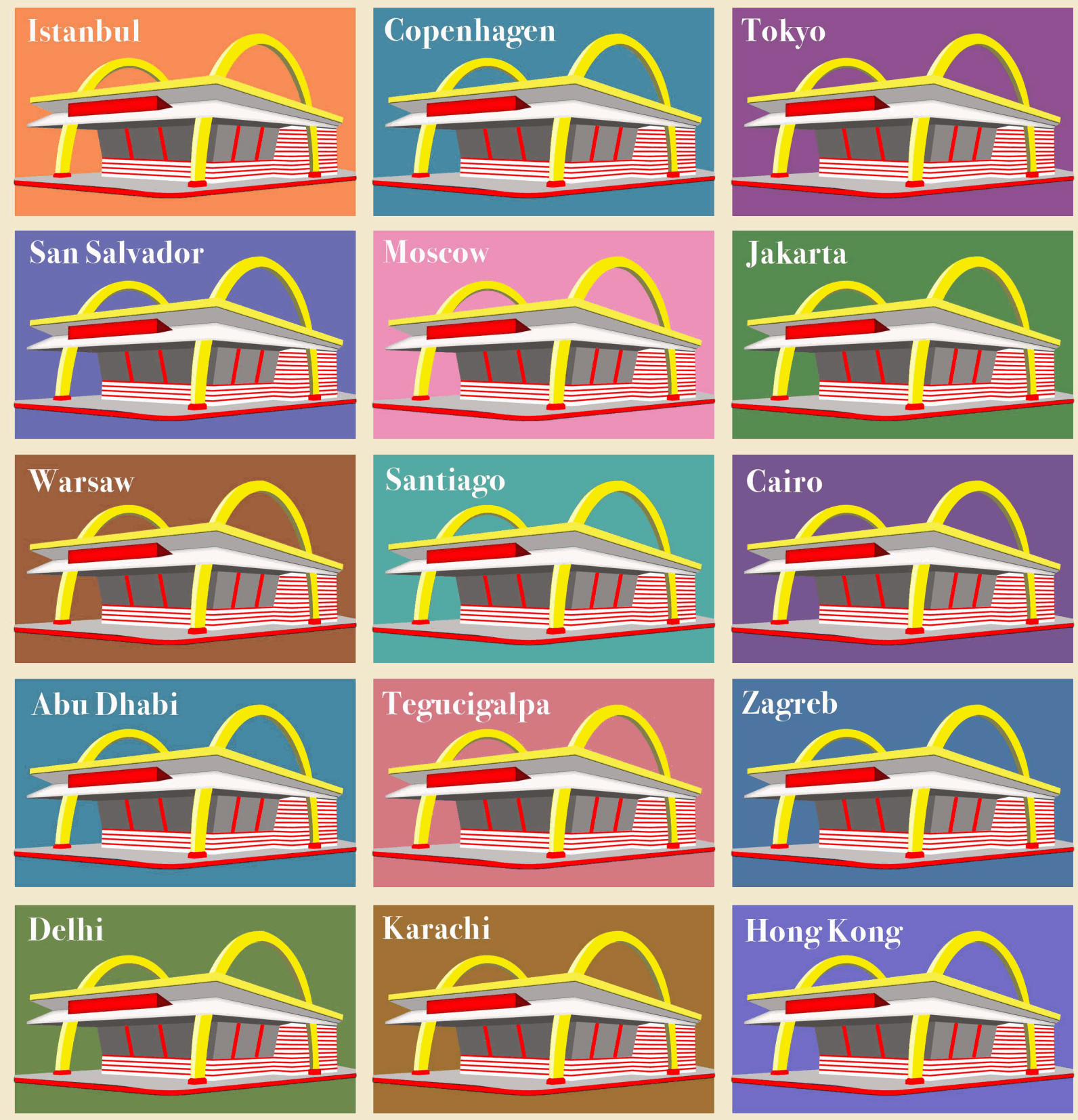

This article is available in Markets, Globalization \& Development Review: https://digitalcommons.uri.edu/mgdr/vol2/ 


\section{Antinomies of Globalization}

\section{Introduction: Refusing the forced choice}

Today, we are told that globalism, or more precisely neoliberal internationalism, is in crisis. The most important symptom of this crisis is the rise of populist forms of nationalism (see, e.g., the MGDR review piece on populism by Gökmen 2017). For any enlightened "secular" subject, the choice between these two options must be clear: Given the racism, ethnicism, chauvinism, sexism or climate denialism of many of the nationalist populist options (think about Trump in US, Farage in UK, Le Pen in France, and so on), even though the economics of neoliberal internationalism has been detrimental in terms of economic injustice and ecological disaster, we should bite the bullet and vote for the "centrist" neoliberal option (Clinton, Remain, Macron, etc.). Nevertheless, one must refuse this forced choice (which has the structure of "your life or your money") and recast the terms of the debate in a manner that opens up the field to other paths to be explored and taken. ${ }^{1}$ The aim of this brief note is to interrogate and deconstruct some seemingly intractable and hardened antinomies of our times, explore how they may be implicated in and constituted by each other's presence, and trace the underlying semantic matrix that governs the relations among the terms in a complexly and unstable network. ${ }^{2}$ Once these hardened antinomies are pulverized into overdetermined contradictions, it will be possible to offer a re-configuration of the organizing problematic that structures and imposes limits to the public debate on how to govern social reproduction.

\footnotetext{
1 In an op-ed prior to the election, Slavoj Zizek (2017) calls this a "false choice" whereas I prefer to read it as a "forced choice" as not choosing the neoliberal internationalist option implies a certain symbolic death in the eyes of the globalist "common sense".

2 Marxian theorist Fredric Jameson (1994) defines antinomy by distinguishing it from contradiction. While the two opposing propositions that make up an antinomy are "radically, or absolutely, incompatible," the contradiction "is a matter of partialities and aspects; only some of it is incompatible with the accompanying proposition" (2). While antinomies are frozen and resist dialecticization, contradictions are productive; they lend themselves to mediation, movement, and transformation. Jameson, rather than choosing between the two, proposes a layered model where antinomies are symptoms of underlying contradictions. Let me also note that Jameson, in distinguishing antinomy from contradiction suppresses another, and according Louis Althusser (1965), properly Marxist concept of overdetermination. This third concept of causality indicates that every conjuncture, site or process is a concatenated and unstable unity of contradictions. In this short note, antinomies will be contaminated and pulled apart towards tracing their overdetermination; in this manner, their ambivalences will be teased out.
} 
The defining antinomy of our post-2008 crash phase, as the forced choice described above suggests, is argued to be the one between neoliberalism and populism. But again as the forced choice above demonstrates, this antinomy is easily grafted onto another, older antinomy between internationalism and nationalism. Older, because implicitly underlying this second antinomy is one between free trade and protectionism - the history of which can be traced to the early periods of capitalism. During the first half of the nineteenth century, in a controversy known as the Corn Law debates, a late-mercantilist configuration of nationstate-capital triad in England insisted on the protection of capitalist agriculture, whereas the emergent industrial bourgeoisie demanded free trade. In this foundational debate of classical political economy, Reverend Thomas Malthus, taking a nationalist position, pushed for the protection of domestic farmers and landed aristocracy. In contrast, David Ricardo, based on his own theory of comparative advantage, argued that free trade would be beneficial not only for Britain but also for every other trading nation. This deep running division, in turn, summons another antinomy between globalization and imperialism. This last antinomy is invoked not only because the nationalist-populist pole tends to mobilize anti-imperialist rhetoric and arguments against what neoliberal internationalists champion as the inevitable historical march of globalization, but also because the latter camp deploys it in order to assert the superior economic efficiency of freetrade over the inefficiencies of inter-imperialist rivalries (protectionism, conflicts, wars, etc.) and therefore the historical necessity and inevitability of world peace under a world market. Table 1, following the Jameson suggestion, layers the three primary antimonies discussed so far.

\section{Table 1: A Layering of Antimonies}

\begin{tabular}{|l|l|}
\hline Neoliberalism & Populism \\
\hline Internationalism & Nationalism \\
\hline Globalization & (Anti-)Imperialism \\
\hline
\end{tabular}

In order to refuse the forced choice imposed on us by such alignment of these antinomies, the card-deck must be re-shuffled so that a more complex and distributed mapping of the relation among these terms can be discerned. Needless to say, as the terms of the antinomies are interrogated and reorganized in new combinations, antinomies will proliferate polysemically: imperialism vs. internationalism, liberalism vs. socialism, democracy vs. authoritarianism, laissez faire vs. planning, market vs. state, global vs. local, early vs. late globalization (see, e.g., Turcan 2016), (late) 
capitalism vs. post-capitalism, and finally, populism vs. counter-populism. And in fact, it would be possible to begin our investigation from any one of these antinomies - as each and every one of them and others that one can conjure up are equally relevant and meaningful points of departure. However, because the three antinomies that line-up as the two poles of the forced choice is the one that our historical conjuncture serves us, we will take them as our entry point and explore the other antinomies as the relations among the terms of the three antinomies are interrogated and reconfigured.

\section{Internationalism: Neoliberal or anti-imperialist?}

Let us begin with the alignment of internationalism with neoliberalism. Without doubt, the so-called marketization (privatization of publicly-owned enterprises, rolling back of welfare transfers) and (trade and financial) liberalization policies that are associated with neoliberalism have indeed contributed to the internationalization of the world economy - both by reconfiguring the role of the nation-state and by increasing the flow of commodities and values across countries. In this sense, there is indeed an internationalist strain to neoliberalism. Or, to put it differently, neoliberal reason has historically pushed for the increased freedom of movement of capital and commodities (but not necessarily humans).

But this lining up of internationalism and neoliberalism must be problematized. First, internationalism, as announced forcefully with the rallying cry, "Workers of the World, Unite!" in Marx and Engels' Communist Manifesto (1848) and institutionalized in the First (1864-1876) and the Second Internationals (1889-1916), has also been historically an anticapitalist and anti-imperialist ideology. In this regard, Marx's own take on the Corn Law debates is worth recalling: Assessing the potential consequences of both protectionism and free-trade on the conditions of working people, Marx (1962[1848]) argued that, despite the fact that a freetrade policy does not necessarily improve their lot, working people should side with the free-trade internationalist as the internationalization of capital would eliminate the feudal remnants and clarify the battle lines between the capitalist classes and the working people. In this version of internationalism, Marx appears to be endorsing Ricardo's view of capitalism as a revolutionizing force but for diametrically opposite reasons.

Nevertheless, the relation between internationalism and nationalism, precisely because of the persistence of imperialism, has been a very difficult question for the socialists and communists as they have historically been caught in between the 1914-1945 debacle of two World Wars interspersed with the Great Depression, on the one hand, and the wave of anti-colonialist 
nationalist liberation revolutions across the world in the second half of the twentieth century on the other (Chatterjee 2012; Nairn 1997). In 1914, the anti-imperialist internationalism of Second International fell into a tragic crisis when the social democrats and socialists of the Great Powers voted for the war decision in their respective parliaments. This experience, combined with the October Revolution in Russia and Lenin's formulation of The Right of the Nations for Self-determination, have led the left to split nationalism into two. Nationalism as the ideology of imperialist Great Powers was rejected as a chauvinism that obscured the fact that imperialist wars and colonial interventions, waged in the name of securing the conditions of existence of the accumulation of surplus value, were against the class interests of the working people (Lenin 1973[1917]). In contrast, anti-colonialist nationalism was endorsed as the self-defense of the colonized people against an Empire that was always compelled to incorporate newer non-capitalist (colonial) territories into its domain not only to exploit their resources but also to use them as fresh markets for selling both consumer and capital goods (Luxemburg 1972[1921]). Interestingly, of course, some of the erstwhile colonies - now free to pursue their national interests - are now offering strong international competition to the workers of the advanced capitalist nations, again forcing workers on each side to choose between the devil and the deep blue sea.

\section{Nationalism: Good and Bad}

Therefore, both internationalism and nationalism are split categories. There are neoliberal as well as progressive internationalisms. Similarly, there are imperialist as well as anti-colonialist nationalisms. Nevertheless, even this division is far from stable. On the one hand, throughout its century long history, many Marxists have been very critical about Soviet Union's instrumentalization of "internationalism" in the name of its own "socialimperialist" designs (e.g., Eastern Europe, Afghanistan). On the other hand, if we were to recall the Bandung conference and its principles, Third World nationalism turned out to be a much more authentically inter-nationalist program than the Cold-War neo-imperialism of Pax-Americana. In 1955, the Bandung Conference brought together many of the then newly-independent Asian and African states and as its central tenet foregrounded peaceful coexistence among equal sovereign nation-states. In the words of President Sukarno (of Indonesia), the host of the conference, the aim was to inject "the voice of reason into world affairs" (cf. Chatterjee 2012, p. 11). In contrast, Pax-Americana persistently meant wars, conflicts, and interventions (e.g., Korean War, Cuba, Vietnam War, Chile, Iran). 
Within this anti-colonialist Bandung rubric, we can also identify the progressive economic character of postwar developmental nationalism. Squarely situated within the Keynesian macroeconomic paradigm that takes the nation-state as the unit of its analysis, versions of post-war developmental governmentality conceptualized development as a means of emancipation from - depending on the particular third world context backwardness, stagnation, underdevelopment, dependency, neocolonialism or unequal exchange; and conceived of economic development as a national project. ${ }^{3}$ "Nationalism," writes Tom Nairn, "was the effort by one 'backward' culture and people after another to appropriate the powers and benefits of modernity for their own use" $(1993$, p. 71$)$.

Of course, the distinctive feature of our modernity has been the process of capitalist accumulation and its internationalizing tendencies. Nationalism figures in, among its other ideological functions, as a social frame to harness and appropriate the powers and benefits of capitalist growth. Yet, this figuration of nationalism - where modernity is represented as a neutral tool and the nation-form refers to a unified people - covers up over two constitutive and interconnected economic cleavages. These are the proper "exploitation" cleavage within the nation and the "unequal exchange" cleavage among the nations. The former cleavage designates a set of "class differences" among those who produce, appropriate, distribute or receive surplus value within a nation. The latter cleavage, on the other hand, designates a hierarchy of nations ranging from those that reap the benefits of the movement of capital (core, center, metropolis) to those that need to defend and pull themselves from being the victims or objects of capital (periphery, satellite; see Dholakia 2018 for a discussion invoking the powerfully simple center-periphery model of Galtung 1980). Without doubt, these two cleavages intersect with each other, forming a matrix of interconnected problems and antagonisms (Dholakia 2018). For instance, all nations, whether they be core, semi-periphery, or periphery, are multiply cleaved by class differences and exposed to the destabilizing effects of class antagonism.

It is thus necessary to invent institutions and discourses that allow class conflict to be subordinated to a relatively effective, durable, and "equitable" "general interest." This allows us to understand in particular why projects of national construction, consequently

${ }^{3}$ That is, until the neoliberal revolution of 1980 s when they are replaced by the highly myopic balance of payments national accounting framework on the macro side and the symptom-level interventionism of "poor economics" on the micro side. For a recent survey of this trajectory, see Akbulut, Adaman and Madra 2015. 
nationalist ideologies in the modern age, have such difficulty presenting themselves as something other than either imperialist or anti-imperialist programs, a way to establish or tear down hegemony. If there is no monopoly to defend or conquer, there can be no state; and if there is no state, there can be no nation (Balibar 2004, pp. 189).

Nevertheless, the nationalist vernacular that is supposed to domesticate and manage the class antagonism will always be deployed in a differential manner, depending on a given nation's relative position within the hierarchy of nations. And it is precisely depending how the nationalist vernacular is deployed and depending on the given social composition and direction of the popular class alliance that is being forged, a nationalism can either be aggressive, chauvinist, imperialist and colonialist; or, conversely, self-defensive, progressive, anti-imperialist and anti-colonialist. Notice that while trying to deconstruct one antinomy (internationalism vs. nationalism), we found ourselves entangled in another one (imperialist vs. anti-imperialist nationalism). Trying to break the alignment between neoliberalism and internationalism, we unpacked the problem of internationalism by theorizing the hierarchies among and within nation-states, without sufficiently problematizing the historical articulation of neoliberalism with the institutional form of nation-state. Let us now turn our attention to this question.

\section{Neoliberal State and Nation}

The alignment between neoliberalism and internationalism can be destabilized from the perspective of neoliberalism as well: Neoliberalism is neither inherently anti-statist nor internationalist. Historically (and for some of its strains, theoretically) neoliberalism, contrary to what its numerous advocates and detractors alike tend to argue, did not entail the rolling back of the state - rather it entailed an epochal reconfiguration of its relation to its subjects (for a recent view from the periphery, see Gago 2017). In contrast to the post-WWII welfare states of advanced capitalist social formations and the developmental state of the Third World, the neoliberal state does not treat its subjects as citizens but rather as consumers or entrepreneurs (Foucault 2008). In other words, even though "small state" has been a rallying cry of the neoliberal revolution, the historical record shows that the nation-states, far from shrinking, have become more involved in regulating and governing the social field-albeit through mechanisms of control. In fact, this is precisely what distinguishes neoliberalism from classical liberalism: While the latter, at least ideologically speaking, aimed at protecting the autonomy of civil society and the markets 
from the interventions of a mercantilist state, the neoliberal counterrevolution aimed at transforming the welfare state by submitting its functions to an audit of economic efficiency and performance (see also, Özgün, Dholakia and Atik 2017). Without doubt, there is a world of difference between the mercantilist state and the welfare state. While the former was a capitalist nation-state still in-formation, the latter is a state that has been forged out of a century-long class struggle and the two world wars. The welfare state has already and irreversibly extended its reach beyond market maintenance (protection of private property, antitrust regulation) all the way into the depths of social reproduction: education, health care, unemployment insurance, childcare, social security, and so on. In that regard, a quick look at the topics discussed in Milton Friedman's Capitalism and Freedom (fiscal policy, education, discrimination, occupational licensure, income distribution, social welfare, and poverty) will demonstrate that the aim of neoliberal counter-revolution is to reconfigure all these functions of the modern welfare state (governmentality) around the assumption that human beings respond to economic incentives. ${ }^{4}$

All of which explains the persistence of the state under neoliberalism, but not the persistence of the nation. Yet, perhaps except for European Union - and even in this case, as the recent case of Brexit demonstrated, by fits and starts - the nation-form and nationalism have not only survived the decades of neoliberal internationalism but re-emerged in the form of the nation qua brand (Aronczyk 2013, Kaneva 2011). Neoliberal thought conceptualizes the international sphere as a competitive realm within which each nation-state competes with one another. The nationhood is turned into a corporate brand that functions as a platform for the ecology of national industries and sectors, promoted through public-private partnership schemes. Turkey presents a relevant example in this context even though it is far from being the most successful one. Since the early 1990s, Turkey, like many other nation-states, has been trying to cultivate a discourse of nationality as a global brand by positioning, in particular, Istanbul as a cultural, financial and transportation hub (Keyder 1999). One could arguably claim that this is a "good" kind of nationalism, one that is competing in a world market, rather than waging wars. Yet, there is, of course, a dark side

4 The specific focus of this paper prevents me from differentiating among forms of neoliberal reason with respect to their respective positions on the uses and limitations of markets. For instance, there is a world of difference between Milton Friedman's vision of capitalism and freedom and Joseph Stiglitz's vision of market socialism, even if both visions are premised upon the working assumption that human beings comprehend and respond predictably to economic incentives. For a discussion of forms of neoliberal reason, see (Madra and Adaman 2014). 
to this kind of corporate nationalism as well. Consider, for instance, the urban displacement and gentrification caused by the production of Istanbul as the European Cultural Capital in 2010. Or, consider the disastrous ecological impact of the third airport (and its associated third bridge across the Bosporus as well as the connecting thruways) that is being built on the northern forests of Istanbul in order to position Turkish Airlines as the locomotive of brand Turkey (Paker 2017). This should not come as a surprise given that the idea of "national interests," especially in neoliberal times, does not only suppress the interests of the local, the dispossessed and the disempowered but is also a decisively anthropocentric notion that defines itself against the backdrop of an utterly exploitable Earth.

The persistence of the nation-state as an economic actor - despite the decades of neoliberal counter-revolution - can also be explained by its increasing role in managing the articulation of the national capital with the international economic order. Throughout the neoliberal decades, again despite the strong anti-state rhetoric, what we observed was a growing emphasis on the strategic capacities of nation-states to promote and enhance national competitiveness in an increasingly internationalized world economy. According to this Schumpeterian vision, the nation-state can function as a central organizing agency that coordinates the allocation of resources to promote technological, organizational and product innovation in order to enhance the structural competitiveness of the nation - both by providing a strong basis for the international competitiveness of national capital and a favorable environment for foreign direct investment. An important distinguishing aspect of this Schumpeterian "workfare" state has been "the subordination of social policy to the demands of labor market flexibility and structural competitiveness" (Jessop 1993, p. 9) - an approach that is fully compatible with the neoliberal critique of the Keynesian welfare state of the postwar era. In other words, internationalization of the world economy does not entail the disappearance of the nation-state but rather its neoliberal transformation. ${ }^{5}$

\section{Globalization: Financing nationalism}

Today, neoliberalism's globalist, end-of-history vision of 'one big world market' is indeed in crisis and the rise of populisms is indeed a symptom of this crisis. But once more we must tread carefully. It is true that the 2008 crash and the subsequent economic depression did not only put a very strong bracket around financialization and securitization, but also demonstrated decisively that the nation-state remains to be an indispensable actor in governing social reproduction at an international

${ }^{5}$ For a recent take on this theme see (Mazzucato 2015). 
scale. Nevertheless, these assertions need to be qualified. First, the bracket around the networks and derivatives of financial capital is yet to be fully enacted. Despite riding the populist resentment against Wall Street before being elected, the Trump Administration is looking forward to dismantle the already timid Dodd-Frank Act (intended to rein in the excesses of finance capital) and the speed of financialization and securitization have quickly resumed its pre-crisis levels (for an immediate post-crisis view, see Dholakia 2011). Yet, there is a widespread agreement that global financial markets have become the key sources of risk for the world economy and polity - even if this agreement has yet to find the right agency and the program to implement its control. In this regard, it is possible to read leftwing populism of Bernie Sanders in the US and Jeremy Corbyn in the UK as the emergence of a political agency and program with the explicit objective of implementing such a control over finance capital -but more on this below.

Second, the internationalized structure of financial markets impose significant limits on the effectivity of the monetary policy interventions of the central banks (the Fed, the ECB, etc.). For instance, the Fed, while intending to inject liquidity to the US economy with "quantitative easing", ended up instead funneling funds towards the emerging financial markets, financing economic growth in these mid-range nation-states (not only BRICS; but also the so-called MINT, namely Mexico, Indonesia, Nigeria and Turkey; see, e.g., Rodner 2017). And, it is precisely this global financial expansion, even after the 2008 crisis, which provided the populist regimes across the globe the funds for consolidating their sovereign hold. On the one hand, these populist regimes used the capital inflow to finance domestic credit expansion. Availability of cheap credit meant for these growing middle classes easier access to new commodities and aspired to life-styles. On the other, this easy money financed the construction sector (through mortgages) as well as the mega infrastructural projects. These construction investments did not only soak up some of the unemployment in the low-skill end of the labor market but also served an ideological function for projecting the grandiosity of the nation-state. The case in point is of course Erdoğan and the resilience of his popular support despite his brand of increasingly authoritarian populist nationalism. In an ironic twist, therefore, financial internationalization became an indispensable condition of possibility of populist nationalism.

In this very practical sense, the very framing of the problem as an irreconcilable antinomy between neoliberal internationalism and populist nationalism does not hold. Not only is the economic feasibility of populist nationalism contingent upon the ceaseless flow of international capital, 
global financial investors are, in turn, hooked on these high-risk high-return securities originating from emerging markets. This symbiotic relationship between financial capital and authoritarian regimes problematizes another doxa of globalism regarding the relation between capitalism and democracy. In recent years, an institutionalist literature has argued that successful long-run growth performance of an economy is directly correlated with the existence of established, stable and strong institutions of market economy, namely, competitive markets, secure property rights, political competition, and a general sense of rule of law. Nevertheless, the increasing internationalization and securitization endows financial capital with an unprecedented elasticity and liquidity to adapt itself to the political risks associated with authoritarian regimes. At the end of the day, as long as there are no restrictions over the movement of financial assets, as long as the authoritarian practices of sovereign nation-states do not disrupt the financial flows, and as long as the risk premium is properly incorporated into the interest rate, there is no reason for international finance not to cooperate with authoritarian regimes.

Yet for all the nations that are plugged into the global financial network, the access to finance does not come without a cost. Increased securitization and liquidity means increased risk of herd behavior, speculative bubble formation (see, e.g., Dholakia and Turcan 2013), and sudden and high volume movements of short-term capital. One way to make sense of the recent resurgence of populist reactions against global finance and peoples' desire to use the nation-state to protect their (imagined) communities is an increasing realization of the vulnerability of societies against the violence of finance and capital accumulation (Marazzi 2011).

\section{Reactionary nationalism}

As already discussed above, the way the nationalist vernacular is deployed and articulated and the social composition of the national populist front (which groups are included and which are excluded) will shape the form that the self-protection of a society will take. It is perhaps the moment to invoke Karl Polanyi's celebrated notion of "double movement" - but only with the proviso that Polanyi himself makes with respect to "fascism" as one of the many possible responses to the crises and excess of the "market system" (2001 [1944], p. 255). Organized societies, to the extent that they can transcend the short-term perspective imposed upon them by economic rationality, may develop institutions and mechanisms to contest and limit the acephalic movement of the circuits of capital. And, the nation-form has historically been quite an effective form in accomplishing this task — until it 
stopped being so with the neoliberal turn. Today, the desire to return to an era before globalization, before neoliberalism, can perhaps be understood in this vein. But, the question that needs to be posed, precisely at this juncture, is the one Polanyi asked during the Second World War: What will be the content of the nation-form that this new populist resurgence deploys in order to protect its imagined community? If, as Partha Chatterjee argues, Empire, and its "prerogative to declare the colonial exception", "is certainly not dead" $(2012$, p. 15, 23), then this question cannot be answered without considering the imperial hierarchy of nations. This question is even more urgent today given all that is evoked by Trump's election slogan: MAKE AMERICA GREAT AGAIN. Writing in 2012, Chatterjee was prescient:

The asymmetry between the economic troubles of the Western powers and their overwhelming military superiority could well open the field for populist resurgence of imperialism, not unlike what was seen in the late nineteenth century. The economic decline of the once privileged is fertile ground for the ugly display of naked power. There are signs already of a growing populist politics in the United States and Western Europe seeking to defend the global privileges of the core body of citizens of these countries against the assertions of lesser powers and the intrusions of alien immigrants (2012, p. 21).

Reading populist resurgence solely from the grid of the forced choice outlined above makes it impossible to see the diversity of forms of populisms. Every populism, to the extent that they must draw a friendenemy line, must take up a position on one side or another of the imperialism/anti-imperialism divide (Gökmen 2017). One must tread very carefully here, however, as imperialism is not a Manichaean order; there is a hierarchy of nations and what appears to be an anti-imperialist nationalism from one perspective might as well be fueled by the promises of pecuniary as well as symbolic spoils of regional imperialist projections. Once again, Erdoğan's recently found anti-imperialist rhetoric is premised upon the defeat of his administration's very own regional imperialist projections regarding the Middle East as well as the increasingly intractable Kurdish question as an "international colony" (Beşikçi 2015).

\section{In lieu of conclusion: Is a trans-local counter-populism possible?}

It is in this precise sense, following Balibar's (2017) formulation, we can distinguish between populism and counter-populism. Balibar argues that nationalist and imperialist forms of populism across the world appropriate and instrumentalize "deep divisions within our societies that neoliberalism 
has either intensified or generated [...] under the terminology of 'anger"' and channel "resentment feelings of insecurity [...] aggressively toward scapegoats and 'internal enemies'". In order to confront these forms of populism, Balibar calls for imagining a "transnational counter-populism" that does not concede the criticism of "the dispossession or disempowerment of the masses in the oligarchic regime" to the imperialist versions of nationalist-populism; and that, instead "seeks and requires the empowerment of the citizenry, therefore pushing its capacity beyond the limits and across the borders that in the past defined the political".

It is important to note that Balibar is not calling for a progressive populist-nationalism but rather a "transnational counter-populism" — the key category being transnational. This new category introduces a further complication to our aforementioned antinomies of globalization. Given that his own writing and politics have historically been preoccupied with the internal as well as external borders of Europe, his choice of "transnational" should not come as a surprise. Moreover, the cycle of revolutionary upheavals - from Athens to Tahrir Square, from Plaza del Sol to Wall Street, and from Wisconsin to Istanbul's Gezi - did indeed announce itself as a transnational phenomenon. Yet, as this cycle of revolutionary uprising against neoliberalism, authoritarianism and their various combinations dissipated, the transnational and trans-local nature of this "global crowd" (Buck-Morss 2015) was lost and their oppositional energies were culled by populist movements that took the nation-form as their container. This recoiling back into the shell of the nation-form happened even when these movements continued to acknowledge the necessity of maintaining a transnational perspective: on the left, Syriza, Podemos, Bernie Sanders and most recently, Corbyn's Labour are all part of the same sequence, even if each followed a different path and in some cases lost their nerve somewhere along the road.

The necessity of maintaining a transnational perspective, while operating within the political frame of the nation-form and enhancing the capabilities of citizens at the local level at the same time is perhaps the most important challenge of all these counter-populisms. Trans-nationality or, if we do not want to override the regional and the local in the name of the national, trans-locality is necessary because the problems that we face are transnational and trans-local: The ecological crisis and the crisis of capitalism are both global problems that cannot be tackled adequately only at the national or the local level - even if all solutions must be built ground up, at the level of micro-politics of subjectivity, by contesting the biopolitical subjectivities of neoliberal forms of governmentality with equal measure. The internal tensions of politics of degrowth illustrates this point perfectly 
(Kallis, Kerschner and Martinez-Alier 2012). On the one hand, "degrowth" is a global, transnational proposition - it requires all the nations to act in a coordinated manner even as its actual implementation also recognizes the legacy of colonial history and the unevenness of development across nations. On the other hand, degrowth is a local, ethico-political proposition - it invites everyone to reflect upon the impact of their consumption patterns on the ecology as well as to question the types of work-life relations cultivated by the neoliberal forms of superego. In between these two poles of the global and the local, a politics of degrowth cannot afford to ignore the scale of national economy and the institutions and dispositifs of the nationstate as terrains of legitimate struggle - even if their very constitution has historically been premised upon harnessing the powers and benefits of modernity in the name of national interest. 


\section{References}

Akbulut, Bengi, Fikret Adaman and Yahya M. Madra (2015), "The Decimation and Displacement of Development Economics," Development and Change 46 (4), 733-61. https://doi.org/10.1111/dech.12181

Althusser, Louis (1965), For Marx. London and New York: NLB.

Aronczyk, Melissa (2013), Branding the Nation: The Global Business of National Identity. Oxford and New York: Oxford University Press.

Balibar, Étienne (2017) 'Populism' and 'counter-populism' in the Atlantic mirror.” openDemocracy, January 2, 2017. (accessed July 14, 2017), [available at https://www.opendemocracy.net/can-europe-makeit/etienne-balibar/populism-and-counter-populism-in-atlantic-mirror].

Balibar, Étienne (2004), We, the People of Europe? Reflections on Transnational Citizenship. Trans. By James Swenson. Princeton: Princeton University Press.

Beşikçi, İsmail (2015), International Colony Kurdistan. London: Gomidas Institute.

Buck-Morss, Susan (2015), "Yerelötesi Müşterekler ve Küresel Kalabalık Üzerine." In Türkiye'de Yeni Iktidar Yeni Direniş: Sermaye-UlusDevlet Karşısında Yerelötesi Müşterekler, Yahya M. Madra and Müge Gürsoy Sökmen, eds. İstanbul: Metis, 29-46.

Chatterjee, Partha (2012), "Nationalism Today," Rethinking Marxism, 24 (1), 9-25. https://doi.org/10.1080/08935696.2012.635023

Davidson, Neil (2012), "The Necessity of Multiple Nation-States for Capital" Rethinking Marxism, 24 (1), 26-46. https://doi.org/10.1080/08935696.2012.635024

Dholakia, Nikhilesh (2011), "Finanzkapital in the twenty-first century", Critical perspectives on international business, 7 (1), 90108. https://doi.org/10.1108/174220411111103859

Dholakia, Nikhilesh (2018), "Borderless Bits: Electronic Globalization in a Volatile Global World", in Information Systems: Debates, Applications and Impacts, Priya Seetharaman and Jocelyn Cranefield, eds. London: Routledge, Chapter 12.

Dholakia, Nikhilesh and Romeo V. Turcan (2013), "Bubbles: Towards a typology", Foresight, 15

79-88. https://doi.org/10.1108/14636681311321095 
Gago, Verónica (2017), Neoliberalism from Below: Popular Pragmatics and Baroque Economies, Durham NC: Duke University Press.

Galtung, Johan (1980), "'A structural theory of imperialism': Ten years later", Millennium: Journal of International Studies, 9 (3), 181-96. https://doi.org/10.1177/03058298800090030201

Gonzales-Vicente, Ruben and Toby Carroll (2017), "Politics after National Development: Explaining the Populist Rise under Late Capitalism," Globalization, 6 , 991-1013. https://doi.org/10.1080/14747731.2017.1316542

Gökmen, Özgür (2017), "Jan-Werner Müller-What is Populism? (2016)" Markets, Globalization and Development Review, 2 (2), Article 7. https://doi.org/10.23860/MGDR-2017-02-02-07

Jameson, Fredric (1993), Seeds of Time. New York: Columbia University Press.

Jessop, Bob (1993), "Towards a Schumpeterian Workfare State? Preliminary remarks on post-fordist political economy," Studies in Political Economy, 40, 40, https://doi.org/10.1080/19187033.1993.11675409

Kallis, Giorgos, Christian Kerschner and Joan Martinez-Alier (2012), "The economics of degrowth," Ecological Economics, 84, 172-80. https://doi.org/10.1016/j.ecolecon.2012.08.017

Kaneva, Nadia (2011), "Nation Branding: Toward an Agenda for Critical Research," International Journal of Communication, 5, 117-41.

Keyder, Çağlar, ed. (1999), Istanbul: Between the Global and the Local. Lanham, Boulder, New York and Oxford: Rowman and Littlefield.

Lenin, V. I. (1973[1917]), Imperialism, The Highest Stage of Capitalism. Peking: Foreign Languages Press.

Luxemburg, Rosa (1972[1921]), "The Questions at Issue," in Imperialism and the Accumulation of Capital, Kenneth J. Tarbuck, ed. London, Allen Lane: The Penguin Press.

Marazzi, Christian (2011), The Violence of Financial Capital. Cambridge, MA: Semiotext(e).

Marx, Karl (1962[1848]), "On the Question of Free Trade" in The Poverty of Philosophy. New York: International Publishers.

Mazzucato, Mariana (2015), The Entrepreneurial State: Debunking Public vs. Private Sector Myths. Second Edition. New York: Public Affairs. 
Nairn, Tom (1997), Faces of Nationalism: Janus Revisited. London and New York: Verso.

Özgün, Aras, Dholakia, Nikhilesh and Deniz Atik (2017), "Marketization and Foucault," Global Business Review 18 (3S), 1-12. https://doi.org/10.1177/0972150917693335

Paker, Hande (2017), "The 'Politics of Serving' and Neoliberal Developmentalism: The Mega Projects of the AKP as tools of Hegemony Building," in Neoliberal Turkey and Its Discontent: Economics Policy and the Environment under Erdoğan, Fikret Adaman, Bengi Akbulut and Murat Arsel, eds. London and New York: I. B. Tauris.

Rodner, Victoria (2017), "Ruchir Sharma, Breakout Nations (2013)", Markets, Globalization \& Development Review, 2 (3), Article 6. DOI:

Turcan, Romeo V. (2016), "Exploring Late Globalization: A Viewpoint," Markets, Globalization \& Development Review, 1 (2), Article 4. https://doi.org/10.23860/MGDR-2016-01-02-04

Zizek, Slavoj (2017), "Don't believe the liberals-there is no real choice between Le Pen and Macron" The Independent, May 3, (accessed June 17, 2017), [available at http://www.independent.co.uk/voices/french-elections-marine-lepen-emmanuel-macron-no-real-choice-a7714911.html] 